\title{
Effect of prostaglandin on estrus response and conception rate in lactating ongole cows
}

\author{
K. Venkata Ramana ${ }^{1}$, K. Sadasiva Rao ${ }^{2}$, K.Supriya $^{3}$ and N.Rajanna ${ }^{4}$ \\ 1.Department of ARGO, College of Veterinary Science, Sri Venkateswara Veterinary University, Prodattur, \\ Andhra Pradesh, India; 2. Department of ARGO, College of Veterinary Science, Sri Venkateswara Veterinary University, \\ Hyderabad, India; 3. Department of Statistics and Mathematics, Agricultural College, Hyderabad, India; \\ 4. Department of Livestock Production and management, College of Veterinary Science, Sri Venkateswara Veterinary \\ University, Korutla, Andhra Pradesh, India \\ Corresponding author: K. Venkata Ramana, email: kvr_vetgyn@yahoo.in \\ Received: 21-11-2012, Accepted: 19-12-2012, Published online: 19-04-2013
}

\section{How to cite this article:}

Venkata Ramana K, Rao KS, Supriya K and Rajanna N (2013) Effect of prostaglandin on estrus response and conception rate in lactating ongole cows, Vet World 6(7):413-415, doi: 10.5455/vetworld.2013.413-415

\begin{abstract}
Aim: The present research work was carried to study the estrus response and conception rate in lactating Ongole cows consequence to double injection of prostaglandin.

Material and Methods: Estrus synchronization was performed by double injection of PGF2 $\alpha$ (Lutalyse, $5 \mathrm{ml} / \mathrm{cow}$ ) in purposively selected 22 lactating Ongole cows. The 1st injection was administered on 60 days post partum (day 0) followed by $2^{\text {nd }}$ injection on 72 days postpartum (day 12 ) and then insemination was carried out at observed estrus.

Results: The ovarian response by ultrasound scanning revealed a dominant follicle of $10.00 \pm 0.78 \mathrm{~mm} 3-4$ days after the PGF2 $\alpha$ administration. Out of 22 cows treated with double injections of prostaglandins 18 cows exhibited estrus within 68.66 $\pm 10.24 \mathrm{hrs}$. The duration of estrus and mean estrous cycle length recorded as $14.20 \pm 2.56 \mathrm{hrs}$ and $21.50+0.21$ days, respectively. The estrous cycle was observed in $79.45 \%$ cows. The remaining cows showed 11-17 (5.48\%), 26-36 (9.59\%) and 37- $60(5.48 \%)$ days of estrous cycle length. The conception rate of observed to be $67.00 \pm 0.26 \%$. The mean calving to service period found to be $81.18 \pm 1.62$ days in lactating multiparous Ongole cows.
\end{abstract}

Conclusion: It may be concluded that double injection of Prostaglandin has reduced the calving to service period which would even truly reduce calving interval in lactating Ongole cows.

Key words: conception rate, estrus response, Ongole cows, prostaglandin

\section{Introduction}

India is the treasure house of Bos indicus breeds [1-2]. The State of Andhra Pradesh situated on the eastern coast of peninsular India is known for the world famous Ongole breed of cattle (Nelore in Brazil). Ongole is a triple purpose (milk, draught and beef) cattle breed. By virtue of their adaptability traits, superior production capacity under harsh tropical conditions, they are very much sought after animals in tropical cattle production. However, certain reproductive impediments like long calving to service period, long calving interval and short estrus duration, incidence and cessation of estrus at night and postpartum anestrous are limiting the economic use of this cattle breed [3-4]. Knowledge of follicular dynamics and estrous behaviour is essential for estimating the best time for artificial insemination and to obtain best conception rate. This situation warrants application of corrective measures to obviate prolonged inter calving period in postpartum lactating Ongole cows. The use of double injection of PGF2 $\alpha$ at 12 days apart was found to be effective in getting

This article is an open access article licensed under the terms of the Creative Commons Attribution License (http://creativecommons. org/licenses/by/2.0) which permits unrestricted use, distribution and reproduction in any medium, provided the work is properly cited. conception rates and comparable with natural estrus [5]. The objective of present research work was to study the estrus response and conception rate in lactating Ongole cows consequence to double injection of prostaglandin.

\section{Materials and Methods}

Ethical approval: Use of animals in this study was approved by the Institutional Animal Ethical Committee as per CPCSEA (Committee for the Purpose of Control and Supervision on Experiments on Animals) Government of India norms.

Twenty two postpartum multiperous lactating Ongole (Bos indicus) cows aged 4-10 years in their $2^{\text {nd }}$ to $5^{\text {th }}$ lactation with the body weight of $350-450 \mathrm{kgs}$ maintained under standard feeding and management at Cattle Project, Live Stock Research Station, Lam Farm, Guntur, $\left(15^{\circ} 00\right.$ and $16^{\circ} 10$ North latitude and $79^{\circ} 04$ and $80^{\circ} 02$ East Longitude), Sri Venkateswara Veterinary University, Tirupati, Andhra Pradesh, India, were included in this study. Estrus synchronization was performed by double injection of PGF2 $\alpha$ (Lutalyse, $5 \mathrm{ml} / \mathrm{cow}$, Pfizer Manufacturing Belgium NV, Rijksweg 12, 2870 Puurs-Belgium). The 1st injection was administered on 60 days post partum (day 0 ) followed by $2^{\text {nd }}$ injection on 72 days postpartum (day 12) and then insemination was carried out at 
Table-1. Effect of double Prostaglandin (PG) on estrus pattern and conception rate

\begin{tabular}{lll}
\hline Sr.No & Parameters & Mean \pm SE \\
\hline 1 & Estrus response (\%) & $82(18 / 22)$ \\
2 & Intensity of estrus (\%) & $9.10(2 / 22)$ \\
& a). Weak & $90.90(20 / 22)$ \\
& b). Normal & $0.00(0 / 0)$ \\
3 & C). Intense & $14.20 \pm 2.56$ \\
4 & Estrus duration (hrs) & $100(22 / 22)$ \\
5 & Ovulatory response (\%) & $4.70 \pm 0.22$ \\
6 & Ovulation time (after the $2^{\text {nd }} \mathrm{PGF}_{2} \alpha$ inj.) & $67.00 \pm 0.26$ \\
7 & Conception rate at induced estrus (\%) & $81.18 \pm 1.62$ \\
\hline
\end{tabular}

observed estrus. All the experimental cows were monitored regularly for estrous symptoms and ovarian cyclicity by regular per rectal gynecological examinations. The ovarian structures in 6 cows designed in investigation were studied daily by a real time B-mode ultrasound scanner using a transrectal $7.5-\mathrm{MHz}$ transducer (Medison 600, Universal Medical Systems, Medison Co., Ltd, Medison Venture Tower 997-10 Daechi-dong, Kangam - Ku Seoul 135-280, KOREA). The data was analyzed by Minitab ${ }^{16}$ (2012) software.

\section{Results and Discussion}

The PGF $2 \alpha$ induced luteolysis appears to be faster in zebu cows [6] which causes the estrum, the ovulatory LH surge and ovulation. The observations recorded by ultrasound scanning revealed a dominant follicle of $10.00 \pm 0.78 \mathrm{~mm} 3-4$ days after the PGF $2 \alpha$ administration (Table-1). The dominant follicle size recorded in this study was in agreement with [7-10]. The ovulation rates recorded in the present study were $100 \%$. The ovulation rate observed was in agreement with the results of [11] in Nelore cows.

Out of 22 cows treated with double injections of prostaglandins 18 exhibited estrus within $68.66 \pm$ $10.24 \mathrm{hrs}$. The time of onset of estrus following PGF $2 \alpha$ injection recorded in this study is corroborating to earlier findings of [6] in Indu Brazil cows and [12-13] in Nelore cows who observed the same of 63.50 and $53.40 \mathrm{hrs}$, respectively.

In the present study, the estrus response recorded lower (82 vs 92) than earlier reports of [3] in Nelore cows. Higher estrus response was reported by in Bos indicus cows [5]. The poor response in the investigation might be due to that this treatment synchronizes follicular growth only by regulating the life span of the corpus luteum.

In the present study, the duration of estrus recorded as $14.20 \pm 2.56 \mathrm{hrs}$ might be due to individual hormonal levels and genetic makeup. The intensity of estrus found to be $90.90 \% \quad(20 / 22)$ exhibited normal while $9.10 \%(2 / 22)$ was weak. This study was in concurrence with the observations of $[7,14]$.

The conception rate was found to be $67.00 \pm 0.26$ $\%$ in PGF2 $\alpha$ treated cows [5] has reported higher conception rate $(90.0 \%)$ than the present findings in Ongole cows, this might be due to better synchrony of ovulation and fertilization as the existing follicles were influenced the next wave of follicles during induction.
The lower percentage of conception rate could be attributed to the ovarian status of cows at which treatment was induced and the type of PGF $2 \alpha$ preparation used [15]. The higher conception rate at induced estrus in cyclic cows might be due to synchrony of ovulation and fertilization as the existing follicular wave influences the emergence of the next wave of follicles formation during induction [4,14-16].

In the present study, the mean calving to service period was $81.18 \pm 1.62$ days which is comparable with results of [5] in beef cattle following synchronization with cloprostenol.

\section{Conclusion}

The study concluded that double injection of Prostaglandin has reduced the calving to service period which would eventually reduce calving interval in lactating Ongole cows.

\section{Authors' contribution}

KVR carried out the experiment under supervision of KSR. KS analyzed the data and NR prepared the manuscript. All authors have read and approved the final manuscript.

\section{Acknowledgements}

The authors express their sincere gratitude to the Sri Venkateswara Veterinary University, Tirupati for providing facilities to carry out the research work at Cattle Project, Livestock Research Station, Lam Farm, Guntur.

\section{Competing interests}

Authors declare that they have no competing interest.

\section{References}

1. Islam, R. (2011) Synchronization of Estrus in Cattle: $A$ Review. Vet. World.4(3):136-141.

2. Narendranadh, M. (1997) The Ongole Cattle - A versatile resource for the tropics. Proceedings of $5^{\text {th }}$ Ongole cattle show. Guntur A.PP30 - 34 .

3. Malik, RK, Singh, P, Singh, IJ, Sharma, RK, Phulia, RK and Tuli, RK. (2011) Chandoliaovarian response and fertility of ovsynch-treated postpartum anestrous Murrah buffaloes. Buffalo Bulletin Vol.30 No.4.

4. Murugavel, K, Yániz, JL, Santolaria, PM, López-Béjar, F and López-Gatius (2011) Prostaglandin Based Estrus Synchronization in Postpartum Dairy Cows: An Update. The International Journal of Applied Research. Vol 7 (4) 145 - 152.

5. Hardin, DR, Warnick, AC and Fields, MJ. (1980) Artificial insemination of subtropical commercial beef cattle 
following synchronization with cloprostenol (ICI 80,996): II, Estrous response. Theriogenology. 14 (4): 259-268.

6. Galina, CS, Orihuela, A and Rubio, I. (1995) Reproductive physiology in zebu cattle, characteristics related to performance and expression of estrus utilized bulls in natural mating. Brazilian Congress on Animal Reproduction 9:46-61.

7. Mialot, JP, Laumonnier, G, Ponsart, C, Fauxpoint, H, Barassin, F, Ponter, AA and Deletang, F. (1999) Postpartum sub estrus in dairy cows; comparison of treatment with prostaglandin F2 $\alpha$ or GnRH + prostaglandin F2 $\alpha+$ GnRH. Theriogenology $52: 901-911$.

8. Roche, JF. (1996). Control and regulation of folliculogenesis - a symposium in perspective. Rev. Reprod 1:19-27.

9. Sakhong Denpong, Thevin Vongpralub, Suporn Katawatin and Saksiri Sirisathein (2011) Ovarian Follicular Patterns and Hormone Profile in Thai Native Cattle (Bos indicus). Thai J Vet Med. 41(4): 439-447.

10. Akter, Z, Talukder, AK, Akter, T, Kabir, MS, Kamal, MM, Bari, FY and Shamsuddin, M. (2010). Ultrasonographic study of ovarian cyclicity in Zebu cows of Bangladesh. Vet Scan Online Veterinary Journal 5 (2). 65-67.

11. Barros, CM, Moreira, MBP, Figueiredo, RA, Teixeira, AB and Trinca, LA (2000) Synchronization of ovulation in beef cows (Bos indicus) using GnRH, PGF2 $\alpha$ and Estradiol Benzoate. Theriogenology 53: 1121-1134.

12. Naidu, GV and Babu Rao, K. (2006) Estrus pattern and conception rate in postpartum lactating Ongole cows. Indian Journal of Animal Reproduction 27 (1) 14- 17.

13. Pinheiro, OL, Barros, CM, Figueiredo, RA, Dovalle, ER, Encarnocao, RO and Padovani, CR. (1998) Estrus behaviour and estrus to ovulation interval in Nellore Cattle (Bos indicus) with natural estrus to Estrus induced with PGF2 $\alpha$ or norgestomet and estradiol Valerate. Theriogenology 49 (3): 667-681.

14. Sahatpure, SK and Patil, MS. (2008): Synchronization of oestrus with Prostaglandin F2 alpha analogue in nondescript cow. Vet. World, 1(7): 203-204.

15. Rao, AV and Venkataramaiah, P. (1985) Studies on the effectiveness of a smaller dose of prostaglandin $\mathrm{F}_{2} \alpha$ in increasing the reproductive efficiency of Ongole cattle. Indian Veterinary Journal 67: 528-530.

16. Gimenes, IU, Sa Filho, MF, Carvalho, NA, Torres Jr, JR, Souze, AH, Madureira, EH, Trinca, LA, Sartorelli, ES, Barros, CM, Carvalho, JB, Mapletoft, RJ and Barruselli, PS. (2008). Follicle deviation and ovulatory capacity in Bos Indicus heifers. Theriogenology. 69: 852-858.

$* * * * * * * *$ 